EDWARD NOWAK

\title{
Results account
}

\section{as a source of economic} information

Prof. Edward Nowak Wroclaw University of Economics Department of Cost Accounting and Management Accounting

\section{Introduction}

Economic activities of companies are geared towards achieving the highest possible profit, which in the long run should result in equity increase. Therefore, company financial result is of fundamental significance in company operation. Its volume reflects the effectiveness of economic processes and, as such, decides on business success in the times of global competition. Consequently, information reflecting company financial result is an important segment of economic data provided by companies to the public.

The most fundamental source of economic information on company financial results and factors influencing the result volume (income and cost) is the company accounting. Results account is a branch of accounting related solely to analysis of company financial results. As such, the results account should provide information both to external and internal stakeholders of an economic entity. For this purpose, the results account is integrated with two basic sections of accounting, namely: financial accounting and management accounting. This integration stems from the fact that company stakeholders have specific information requirements. 
This paper discusses the problems of results accounting as part of company accounting process. The main purpose is to present the role of results account as a source of economic information that may be useful for both external and internal stakeholders in their decision-making processes. This objective is realized through literature studies of domestic and foreign publications on accounting, as well as analyses of Polish and international regulations with respect to accounting and financial reporting.

\section{Measuring company results as an accounting task}

Economic measurement of company performance, including company financial results, is one of the most fundamental tasks of accounting. Measurement is regarded as one of the most important ways to obtain economic information for the purpose of uncertainty reduction (Hubbard, 2007, p. 42). The orientation on economic measurement of company performance is well-reflected in many definitions of accounting. Below are some examples of such definitions, formulated by professional organizations and selected authors.

As early as 1953, the American Institute of Certified Public Accountants (AICPA) defined accounting as an art of recording, classifying and summarizing economic information for the purpose of rational evaluation and facilitating the decision-making processes by users of such information (American..., 1953). Similar observations on the nature of accounting are formulated in 'A Statement of Basic Accounting Theory' (ASOBAT), published by the American Accounting Association (AAA). This document defines accounting as the process of identifying, measuring and communicating economic information to permit informed judgments and decisions by users of the information through identification of risks related to economic operation (Evanston 1966, p. 1).

Economic measurement in retrospective dimension as a subject of both theory and practice of accounting was emphasized by R. Mattessich (1965, p. 17). In his approach, accounting involves quantitative description of company activities, based on measurement of economic quantities. Similar perspective in defining the subject of accounting is expressed by Y. Ijiri (1965): accounting deals in economic measurement undertaken for the purpose of managing the activities of economic entities. A concise definition of accounting in relation to economic measurement is postulated by A. Kinserdal: $(1995$, p. 1) accounting is a system of measuring economic activity and communicating the result of these measurements to users. 
Polish professional literature also provides interesting approaches to the subject of accounting. M. Dobija (1999, p. 43) elaborates on the concepts by R. Mattessich and Y. Ijiri, defining accounting as a system of measuring economic quantities of objects participating in processes of economic entities. J. Kuchmacz (2010) describes the fundamental goal of accounting as measuring profit made by an economic entity.

Orientation on measurement of economic results is closely related to the significance associated with this particular financial category. Profit made by an economic entity is thus (Hendriksen, Van Breda, 1992, pp. 323-324):

- a reliable measure of effectiveness in company operation,

- a method of increasing the invested capital,

- a tool for predicting future company development,

- a basis for predicting future distribution of divident,

- a basis for evaluation of task completion,

- a criterion used in economic decision-making processes.

The findings obtained through measuring company results constitute a set of economic information that can be employed in the realization of economic tasks. Measurement of economic quantities is delegated to a relatively distinct subset of accounting referred to as results account. Results account involves computational and recording activities aimed at identification and presentation of information on financial results of economic entities (Nowak 2009, p. 182).

However, there are no universal methods of measuring financial results of economic activities. This problem can be solved in two ways. One solution is to adopt a unified concept that can be reliably used to tackle diverse tasks assuming that such a concept is at all possible. The alternative approach is to adopt different concepts of results measurement, each suited to a particular task at hand (Hendriksen, Van Breda 1992, pp. 323, 352-354). A unified concept cannot reliably address all the tasks involved in results account. Therefore, the most applicable principle in results account can be presented as follows: different methods of result measurement for different purposes.

Taking into account the target recipient of information on company results, two categories can be distinguished:

- results account as part of company financial accounting, oriented on providing information to external recipients (external stakeholders),

- results account as part of company management accounting, oriented on providing information for internal stakeholders.

Correlation between those two categories of accounting is presented in fig. 1. 


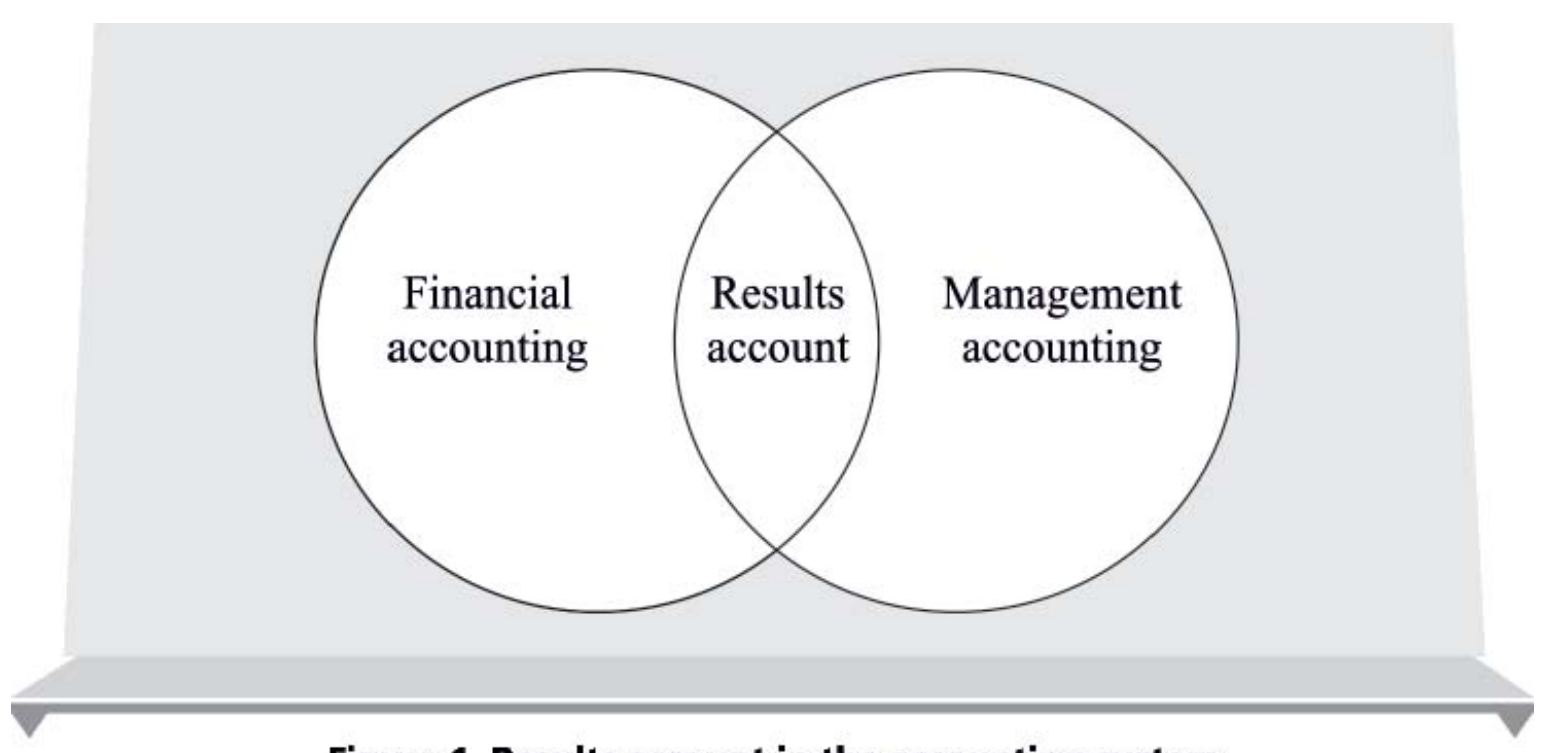

Figure 1. Results account in the accounting system

Source: own study

Fig. 1 illustrates the placement of results account in the system of accounting. Results account is a source of information presented in financial reports (financial accounting), as well as information utilized in the course of managing company operation (management accounting). Regardless of the adopted methods of measurement, the results account provides information used for both precise evaluation of the situation and for making more appropriate decisions. To fulfil such disparate information requirements, the result measurements should be grouped according to suitable criteria and obtained using suitable methods of measurement. This task is discussed in the next section of this paper.

\section{Results account for reporting purposes and its informative significance}

Companies are obliged to carry results account for the purpose of financial reporting within the system of financial accounting. This orientation of results account makes it a relatively isolated subsystem of the recording-reporting system in financial accounting. Results account is a systematic register of current expenses and revenues, recorded as they occur and presented periodically together with results in financial reports. This type of account must be consistent with accounting norms: principles, standards and legislative regulations. 
The results account for reporting purposes provides information for the benefit of external recipients. The account should be carried in a form that ensures:

- determination of company revenues, expenses and financial results, as well as presentation of the above in the form of profit-and-loss accounts (in accordance with accounting norms),

- determination of taxable income and settlement of income tax dues (in accordance with the Act on Income Taxation),

- preparation of statistical reports: quarterly F-01 and annual F-02 (in accordance with legislative regulations on official statistics).

The level of financial result determined in financial accounting is largely dependent on the adopted principles of accounting. The results account produced for reporting purposes measures financial result using the historical cost (price) convention. This means that the account is carried using actual purchase prices or costs incurred in terms of their monetary value, expressed in nominal currency units. Furthermore, the financial result is calculated on the accrual basis. The accrual principle states that expenses are recorded at the date of their occurrence, and not at the date of final settlement of dues for services or assets used. The recording of revenues follows the same principle: income is registered at the moment of recognition of proceeds, and not at the reception of payment for assets sold. Another important determinant is the conservatism principle: one should register only factual income and factual expense incurred - this also applies to credible expenses. The level of financial result is also related to the matching principle, which states that revenues for a given reporting period have to be matched with corresponding expenses, regardless of the reporting period they were associated with in the first place. The above principles explain why the financial result for financial accounting purposes is often described in terms of 'book value'.

The accounting principles lack an explicit definition of financial result. This notion is defined indirectly, a quantity resulting from calculation of all other economic categories subject to accounting measurement. These are: assets and liabilities, equity, revenues and expenses. This is why proper identification of elements constituting the results account is of utmost importance.

The financial result in financial accounting is determined as a difference between income and cost. Definitions of the two financial categories in the Polish Accounting Act are similar to those used in the International Financial Reporting Standards (IFRS). Thus, income is defined as probable economic benefits of a reliably estimated value, which may arise during a reporting period in the form of increases in the value of assets or decreases in the value of liabilities, that will 
result in an increase of the equity or a decrease of the equity deficit in a manner other than through contributions made by shareholders or owners. Costs represent probable decreases of economic benefits of a reliably estimated value, which may arise during a reporting period, in the form of decreases in the value of assets or increases in the value of liabilities and provisions, that will result in a decrease of the equity or an increase of the equity deficit in a manner other than through withdrawal of funds by shareholders or owners (International..., 2011, p. A49).

Calculation of financial result is largely dependent on the concepts of capital and capital preservation adopted for the purpose of financial reporting. Typically, for reporting purposes, companies adopt the financial concept of capital. In this concept, 'capital' is a synonym of 'equity' or 'net assets'. Equity (net assets) is a difference between assets and liabilities. This concept is a point of reference for the calculation of profit. In line with the financial concept of capital, profit is generated only when the value of net assets at the end of a reporting period is higher than the net assets reported at the start of the same reporting period, adjusted against any contributions or withdrawals made by owners for the period under analysis. Thus, profit represents only this part of net asset increase that is in surplus of the volume needed for capital preservation. This is why profit is defined as a difference between income and cost. If the opposite takes place, the company is considered in loss (International..., 2011, p. A55)

Similar definition of financial result is used in the Statement of Financial Accounting Concepts (SFAC), issued by the Financial Accounting Standards Board (FASB). The relevant entry was introduced in 1980 in SFAC No.3, superseded in 1985 by SFAC No.6. In FASB terminology, financial result represents a change of in net assets occurring during the period as a result of transactions and other events taking place in relations with economic actors other than owners (SFAC No. 3).

Definitions of financial result formulated by IASB and FASB are based on the concept of comprehensive income. In this approach, profit is regarded as an instrument for increasing the equity value. As such, it contributes to an increase of wealth for company owners. This is why determination of financial result takes into consideration all changes in net assets resulting from transactions or asset revaluation in a given period. Any changes resulting from owner contributions and withdrawal are excluded.

Another concept used in determination of financial result is the concept of operational result. Operational result is regarded as a fundamental measure of company achievements. It is also used as basis for evaluation of operational 
effectiveness, i.e. optimal use of resources. Operational result is calculated as difference between income generated and expenses incurred in a given period.

Operational result examines only those economic transactions that are influenced by company management and result from management decisions made in a given period. Those transactions come as a result of systematic operational activities, as opposed to incidental events of unique character. At the same time, any revaluations of assets at the end of the reporting period are related to net assets. To calculate the net result, the financial result is adjusted against results of incidental events.

Comprehensive income is wider in scope than the net result, since it includes the additional value of cumulated results of changes in the adopted accounting principles, revision of some net asset items, as well as other changes in equity not related to ownership. Those changes are largely an effect of events occurring in company environment, which are mostly outside the company influence.

The concept of operational result is reflected in the profit-and-loss account. The concept of comprehensive income, on the other hand, is adopted to reflect changes in net assets. At present, the general trend is to adopt a mixed approach, aimed ad reconciling the two concepts. In this approach, some items on income and cost accounts (such as capital from revaluation of asset components) are directly related to net assets. The formula of profit-and-loss account adopted in Poland at present is an example of such a mixed approach. However, many countries adopt regulations based strictly on the concept of comprehensive income, in accordance with the recommendations issued by the International Financial Reporting Standards (Grabiński 2012).

\section{Results account for the purpose of company management}

The results account variant presented in the preceding section is carried for the purpose of producing a profit-and-loss account as an obligatory element of the financial report. This type of account, however, offers limited capacity in regard to producing information useful for the management processes, especially in the short-term perspective. One type of results account designed to provide information for internal management processes is the short-term profitand-loss account. This form of account is particularly suitable for economic decision-making purposes in the face of fluctuations in product sale or unused production capacities.

Short-term profit-and-loss account is closely related to variable costs account. As such, it is based on distribution of costs of basic operational activities into 
variable costs (related to production volume) and fixed costs (which are unrelated to production output). This classification of costs is of utmost significance for the purpose of decision-making in short-term perspective. In short-term profit-andloss account, variable cost represents product cost related to product. Period cost represented in its entirety in the results account for the period in question is represented as fixed cost. This approach, however, is contrary to the requirements of financial reporting. According to reporting norms, product cost represents the cost of production, while period cost is associated with non-production cost (such as cost of sale and management).

One important result category calculated within the short-term profit-and-loss account is the contribution margin. Contribution margin represents a surplus of product sales income against variable costs. In short-term perspective, fixed cost remains unchanged and, consequently, is not considered significant for decisionmaking in short-term perspective. This is why the surplus cannot be regarded as profit, and for this reason, this category is referred to as contribution margin (Proctor 2006, p. 104). Contribution margin should be high enough to ensure full coverage of fixed costs and provide profit from product sale. It is, therefore, a measure of profitability in short-term perspective.

In the most straightforward scenario, the short-term results account can be expressed as follows:

total sales revenue

- total variable costs

contribution margin

- fixed costs

sales result

The result from product sale is then a surplus of global contribution margin over fixed costs.

However, the above diagram of a short-term profit-and-loss account has two important limitations and can only be used to describe single-product manufacturing systems. One limitation lies in the fact that fixed costs incurred over a given period are represented as a single global value, offering no capacity of detailed examination and control. The other limitation is the lack of potential for evaluation of profitability by segment of activities, since contribution margin is also represented by a single global value. For these reasons, professional literature postulates two specialized variants of the short-term results account, namely: multi-stage results account and multi-block results account (Nowak 2011). 
A multi-stage account of results takes into consideration all constituent ranges of fixed costs to calculate contribution margin in a gradual process. The procedure can be expressed as follows:

product sales revenue

- variable cost of production

contribution margin I

- fixed cost by department

contribution margin II

- fixed costs of sale

contribution margin III

- total cost of management

sales result

A multi-block variant of results account analyses various segments of company operation. The segments are determined using the following criteria:

- subjective scope: company, divisions, branches, departments,

- objective scope: sum of activities, activities by form, assortment groups, product,

- distribution: total sales, sales by region, distribution channels, customers.

For each designated segment of activities, a separate contribution margin is calculated as basis for evaluation of effectiveness. The margin is also a criterion for evaluation of activities of individual results centres (units involved in result generation).

\section{Conclusions}

Results account is a fundamental source of information for the purpose of evaluating the profitability of company activities. Methods employed in results calculation are varied, depending on the objective and the target recipient of results information. Results account carried for the purpose of reporting is designed to provide information to external stakeholders, and the resultant information is used mainly for long-term decision-making. This variant of results account is unsuitable for short-term management purposes, with large fluctuation of demand. This applies, most of all, to the use of production capacities, setting profitability thresholds, determining minimum price limits, selection of optimum production structure, and the choice between manufacturing and subcontracting individual components. These decisions are made on the basis of information provided by short-term results accounts carried for the purpose of internal management. 


\section{Summary}

\section{Results account as a source of economic information}

Financial result is one of the fundamental economic categories subject to measurement within the accounting system. Financial result is a complex economic category, since its fluctuations are determined by expenses and revenues. The volume of financial results is related to activities in each of the individual areas of business operation and to selected external factors. Information on company results is of interest to all stakeholders, both internal and external, but the information requirements of each group are dissimilar. One common denominator here is the use of financial information in economic decision-making processes. This paper presents the role of results account as an important source of information used for decision-making purposes by company stakeholders, both external and internal.

Keywords: results account, economic information, financial reporting, results management.

\section{Streszczenie}

\section{Rachunek wyników jako źródło informacji ekonomicznych}

Wynik finansowy jest jedną $\mathrm{z}$ podstawowych kategorii ekonomicznych podlegających pomiarowi $w$ systemie rachunkowości. Przy tym wynik ten jest złożoną kategorią ekonomiczną, gdyż kształtuje się pod wpływem ponoszonych kosztów i osiąganych przychodów. Wielkość wyniku finansowego zależy od działań podejmowanych $\mathrm{w}$ różnych obszarach aktywności biznesowej przedsiębiorstwa a także od czynników zewnętrznych. Wynikami osiągniętymi przez przedsiębiorstwo interesują się różni interesariusze: zewnętrzni i wewnętrzni, przy czym ich potrzeby są odmienne. Wspólną ich cechą jest wykorzystanie informacji finansowych przy podejmowaniu decyzji ekonomicznych. Artykuł niniejszy ukazuje rolę rachunku wyników jako ważnego źródła informacji na potrzeby podejmowania decyzji przez różnych interesariuszy przedsiębiorstwa: zewnętrznych i wewnętrznych 


\section{Słowa}

kluczowe: rachunek wyników, informacje ekonomiczne, sprawozdawczość finansowa, zarzadzanie wynikami.

\section{References}

1. American Institute of Accountants, Review and Resume, (1953), "Accounting Terminology Bulletin" No. 1 AIA, New York.

2. Evanston J.L. (1966), American Accounting Association, A Statement of Basic Accounting Theory, AAA, New York.

3. Grabiński K. (2012), Sprawozdanie z zysku całkowitego a bieżacy zysk operacyjny - użyteczność decyzyjna w świetle badań naukowych, "Zeszyty Teoretyczne Rachunkowości" nr. 66 (122).

4. Hendriksen E.S., Van Breda M.F. (1992) Accounting Theory, Richard D. Irwin INC., Chicago.

5. Hubbard D.W. (2007), How to Measure Anything. Finding the Value of Intangibles in Business, Harvard Business School Publishing Corporation, Harvard.

6. Ijiri Y. (1965), Axioms and Structures of Conventional Accounting Measurement, "The Accounting Review", January.

7. International Financial Reporting Standards, (2011), IFRS Foundation, London.

8. Kinserdal A. (1995), Financial Accounting. An International Perspective, Pitman Publishing, London.

9. Kuchmacz J. (2010), Rachunkowość podwójna jako system pomiaru kapitału i zysku, in: Dobija M. (ed.), Teoria pomiaru kapitatu i zysku, Wydawnictwo Uniwersytetu Ekonomicznego w Krakowie, Kraków.

10. Mattessich R. (1965), Accounting and Analytical Methods, IRWIN, Homewood.

11. Nowak E. (2009), Wynik finansowy przedsiębiorstwa, in: Czubakowska K., Gabrusewicz W., Nowak E. (2009), Przychody. Koszty. Wynik finansowy przedsiębiorstwa, PWE, Warszawa.

12. Nowak E. (2011), Rachunkowość zarządcza w przedsiębiorstwie, CeDeWu, Warszawa.

13. Proctor R. (2006), Managerial Accounting for Business Decisions, Prentice Hall. Financial Times, Harlow.

14. SFAC No 3 Elements of Financial Statements of Business Enterprises (1980), FASB, New York.

15. SFAC No 6 Elements of Financial Statements (1985), FASB, New York. 